\title{
Integrasi Organisasi Masyarakat Sipil (Civil Social Organization) di Lingkungan Sekolah
}

\author{
NUR ENDAH JANUARTI \\ Jurusan Pendidikan Sosiologi FIS UNY \\ e-mail : endahjanuarti@uny. ac. id
}

\begin{abstract}
Abstrak
Penelitian bertujuan memahami bentuk integrasi organisasi masyarakat sipil terkait dengan pendidikan kearifan lokal untuk memahami substansi, peran serta implementasinya di SD Sendangsari dan lingkungan Desa Sendangsari. Menggunakan metode kualitatif, pengumpulan data dengan observasi non partisipan, wawancara dan dokumentasi. Informan penelitian adalah guru, siswa dan karyawan SD Sendangsari; Dinas Pendidikan, masyarakat dan organisasi masyarakat sipil yang terlibat dalam proses pendidikan di sekolah. Analisis data menggunakan teknik interaktif (Interactive Model of Analysis) terdiri atas reduksi data, penyajian data dan penarikan kesimpulan. Hasil penelitian menunjukkan bahwa Organisasi Masyarakat memiliki peran membentuk sebuah interaksi antara pihak instansi pendidikan atau lembaga pendidikan untuk membangun komunikasi dengan kelompok, komunitas di masyarakat. Organisasi masyarakat tersebut berupa Paguyuban Kearifan Lokal Orang Tua Murid, Organisasi Pemuda Karang Taruna dan Sanggar Anak Bumi Tani. Wujud integrasi sosial organisasi masyarakat menjadikan sekolah memiliki fungsi sebagai ruang partisipasi sosial, sarana pemberdayaan sosial organisasi masyarakat, dan sebagai ruang transformasi budaya.
\end{abstract}

Kata kunci : organisasi masyarakat sipil, sekolah, integrasi.

\begin{abstract}
This research aims to know the integration of civil society organizations in relation to the local wisdom education to understand the substance, role, and its implementation at Sendangsari Elementary School and Sendangsari village. This research utilizes qualitative method. The data were gathered using observation of non-participants, interview and documentation. The research informant includes teachers, students, staffs at Sendangsari Elementary Schools, educational office, society, and civil society organization that are involved in the educational process at school. The data were analyzed using Interactive Model of Analysis which consists of data reduction, presentation, and conclusion. The findings show that society organizations have roles to enhance educational institutions to build interaction with groups or communities in the society. The society organizations include Local Wisdom of Students Parents, Youth Organization, and Bumi Martani Arts Houses. The realization of social organization integration causes the schools to function as a space for social participation, social organization empowerment, and cultural transformation.
\end{abstract}

Keywords: civil society organization, school, integration 


\section{PENDAHULUAN}

Publik atau didefinisikan sebagai rakyat dalam sebuah konsep bangsa adalah sebuah terjemahan yang cukup panjang ketika secara dialogis dipertemukan dengan berbagai struktur sosial. Konsep publik atau masyarakat dapat dengan mudah dimanfaatkan oleh politisi terkait dengan berbagai bentukan kebijakan dan pemikirannya. Manipulasi suara publik untuk mencapai kekuasaan bisa de ngan mudah dilakukan dalam kancah perpolitikan dan kontestasi kekuasaan. Tanpa adanya organisasi, struktur serta prinsip, publik tidak akan berarti bagi demokrasi. Demokrasi khususnya demokrasi liberal 'yang sehat' tentunya publik juga diperlukan sebagai publik yang terorganisir untuk demokrasi, tersosialisasikan dengan ragam norma serta nilainya dan berkomitmen de ngan bukan untuk kepentingan sempit namun pada tujuan yang lebih luas. Komunitas sipil seperti ini dimungkinkan melalui suatu 'masyarakat sipil' yang dinamis (Larry Diamond, 2003:278).

Masyarakat sipil yang melingkupi kehidupan sosial terorganisasi dengan terbuka, sukarela, dan lahir secara mandiri. Masyarakat secara otonom berswadaya secara parsial dengan tatanan legal atau seperangkat nilai bersama. Masyarakat sipil sebagai penengah, berdiri diantara ruang privat dan negara bukan sebagai masyarakat ekonomi yang memiliki tujuan utama mencari keuntungan, namun adalah untuk menciptakan norma dan pola keterlibatan kultural yang dapat meluas ke ruang public (Larry Diamond, 2003:278). Kehadiran masyarakat sipil menjadi satu nuansa keterpakaian aspirasi masyarakat melalui aktivitas nyata dalam ruang yang hadir dalam sebuah negara. Antara penguasa dan rakyat, ada satu elemen yang memberikan kesempatan untuk dapat turut menjembatani serta mengkaji lebih lanjut terhadap berbagai macam kuasa elite dan suara masyarakat. Pemerataan dan pembangun demokrasi yang sebenarnya ada dalam kausal masyarakat sipil akan dapat menentukan terhadap keberhasilan pembangunan demokrasi di negara ini.
Ketika membahas mengenai masyarakat sipil, ketercakupan masyarakat sipil tentunya dalam berbagai aspek dan segi. Beragam organisasi, formal dan informal yang memiliki nilai-nilai serta landasan bersama dengan saling diusung untuk mewujudkan pembangunan demokrasi masyarakat secara menyeluruh. Berbagai macam diantaranya disebutkan oleh Larry Diamond yakni masyarakat sipil dalam bidang ekonomi, kultural, informasi dan pendidikan, kepentingan, pembangunan, berorientasi isu dan kewarganegaraan. Masyarakat sipil yang melakukan perhatiannya pada tujuan publik akan menggunakan landasan berpikir serta pijakan orientasi nilai di dalamnya dengan bukan tujuan privat. Artinya bahwa ada landasan nilai tersebut menjadi satu pedoman yang kemudian diimplementasikan dalam aktivitas masyarakat sipil.

Organisasi Masyarakat Sipil (OMS) sebagai sebuah organisasi di masyarakat turut mewujudkan prinsip masyarakat sipil yakni adanya pluralism dan keberagaman yang bertentangan dengan orientasi pasar. Pemberdayaan, perantara aktivitas antara masyarakat dan negara menjadi satu prinsip yang diusung organisasi masyarakat sipil. OMS dalam implementasi nilai atau prinsip dasar dapat melakukan berbagai aktivitas yang dapat turut membangun pembangunan masyarakat dan demokrasi. Integrasi orga nisasi masyarakt sipil dalam berbagai bidang mampu melahirkan kekuatan-kekuatan baru dalam pembangunan masyarakat.

Pendidikan terbangun atas proses yang menjadi sebuah cara untuk mereduksi ber bagai pengetahuan dan kemampuan masyarakat. Pendidikan memainkan peranan penting dalam kehidupan manusia ketika pendidikan mampu mempengaruhi perkembangan fisik, daya jiwa (akal, rasa, kehendak, sosial, dan moralitas. Pendidikan dapat dipandang dalam arti luas dan dalam arti teknis atau dalam arti hasil dan dalam arti proses (Sumitro dkk, 2006:17). Pendidikan dalam arti luas menunjuk pada suatu tindakan atau pengalaman yang mempunyai pengaruh yang berhubungan dengan pertumbuhan atau perkembangan jiwa (mind), watak (character) atau 
kemampuan fisik (physical ability) individu. Dalam arti teknis pendidikan adalah proses yang mana masyarakat, melalui lembagalembaga pendidikan (sekolah, perguruan tinggi atau lembaga-lembaga lain) dengan sengaja mentransformasikan warisan budayanya, yaitu pengetahuan, nilai-nilai dan keterampilan dari generasi-ke generasi.

Pendidikan dalam arti teknis merupakan sebuah proses reduksi atas pengetahuan melalui saluran-saluran yang ada di dalam masyarakat diantaranya sekolah. Sekolah sebagai pranata pendidikan hadir sebagai struktur masyarakat yang melanggengkan dirinya sebagai sebuah institusi sosial diantara berbagai institusi yang lain seperti institusi politik, ekonomi, teknologi, dan budaya, secara struktural fungsional memiliki fungsi dan esensial tertentu bagi kelangsungan hidup masyarakat tersebut. Sebagai salah satu lingkungan terjadinya kegiatan pendidikan, masyarakat memiliki pengaruh besar terhadap berlangsungnya segala kegiatan yang menyangkut masalah pendidikan. Disebutkan oleh Ary Gunawan dalam Sosiologi Pendidikan bahwa sekolah dalam masyarakat memiliki pertalian yang sangat erat. Diantaranya melalui analisis pola-pola interaksi antara sekolah dengan kelompok-kelompok sosial lainnya di dalam masyarakat yakni masyarakat akan turut mempengaruhi atas terlaksananya organisasi sekolah, proses pendidikan yang terdapat dalam sistem sosial dalam masyarakat dan luar sekolah, adanya hubungan antara sekolah dengan masyarakat dalam pelaksanaan pendidikan, serta pengaruh faktor demografi dan ekologi dalam masyarakat yang bertalian dengan organisasi sekolah yang perlu untuk memahami sistem pendidikan dalam masyarakat serta integrasinya di dalam keseluruhan kehidupan bermasyarakat (Ari Gunawan, 2000:54). Artinya dalam hal ini masyarakat sebagai tempat berlangsungnya proses pendidikan melalui institusi sekolah jelas turut mempengaruhi proses pendidikan yang ada di dalam sekolah. Masyarakat dengan segala struktur dan pola yang ada di dalamnya merupakan ba ngunan atas modal-modal sosial yang diperlukan bagi institusi pendidikan atau sekolah sesuai dengan pola atau program pendidikan yang dilaksanakan. Dalam kapasitas partisipasinya terhadap institusi pendidikan dalam hal ini sekolah tentunya masyarakat memiliki batasan masing-masing sesuai dengan program pendidikan yang dilaksanakan.

Undang-Undang Nomor 20 Tahun 2003 tentang Sistem Pendidikan Nasional terdapat konsep penyelenggaraan pendidikan secara demokratis dan berkeadilan. Pendidikan demokratis merupakan sebuah konsep yang memberikan kebijakan dengan mendorong pengelolaan sektor pendidikan pada daerah dengan diimplementasikan di tingkat sekolah. Berbagai perencanaan, pengembangan sekolah, baik rencana pengembangan sarana dan alat, ketenagaan, kurikulum serta ber bagai program pembinaan siswa, semua di serahkan pada sekolah untuk merancang serta mendiskusikan dengan mitra sekolah atau komite sekolah. Selanjutnya berkembang pada hal tersebut dalam undang-undang terletak adanya proses keterlibatan masyarakat dalam pengembangan sektor pendidikan. Tercantum pada pasal 9 berbunyi "masyarakat berhak untuk berperan serta dalam pe rencanaan, pelaksanaan, pengawasan dan evaluasi program pendidikan" (Nn, 2006:78). Sehingga inilah yang kemudian menjadi sebuah kekuatan dalam penyelenggaraan pendidikan secara demokratis terutama di daerah dalam perumusan kebijakan secara otonom yang kemudian diimplementasikan di sekolah. Sekolah juga memiliki kewena ngan untuk dapat melaksanakan berbagai program pendidikan dengan melakukan proses kerjasama dengan partisipasi masyarakat baik komite sekolah, komunitas dan sebagainya.

Harapan terwujudnya integrasi organisasi masyarakat sipil yang berkembang pada kurun waktu terakhir seiring dengan dinamika sistem pendidikan di Indonesia adalah adanya integrasi organisasi masyarakat sipil dengan dunia pendidikan. Kurikulum pendidikan berbasis kearifan lokal yang merujuk pada sebuah nilai universal tentang keadilan sosial, kesejahteraan masyarakat dan kelestarian sumberdaya penghidupan masyarakat dengan melandasi 
pola hubungan antar warga atau komunitas lain menjadi salah satu pijakan nyata dalam pengembangan eksistensi pendidikan di masa saat ini.

Sebuah sistem sosial yang terbangun dari hubungan manusia dengan lingkungan tempat tinggal akan saling berpengaruh. Sebagai fakta sosial menurut Durkheim, lingkungan atau tempat tinggal dalam hal ini masyarakat akan memberikan penguasaan secara umum yang mempengaruhi aktivitas hidup individu di dalamnya. Kearifan merupakan identik dengan penghargaan manusia atas sumberdaya alam yang mendukung kehidupan yang tercermin pada pengetahuan dan perilaku sehari-hari.

Ketika memahami pendidikan sebagai ruang yang efektif untuk mempertahankan dan mengembangkan kearifan lokal, keberadaan komunitas menjadi satu hal yang dikaji dalam hal ini. Ruang pendidikan kearifan lokal merupakan ruang publik yang melibatkan berbagai elemen masyarakat secara luas. Diantaranya adalah keberadaan kelompok masyarakat atau organisasi masyarakat yang turut terintegrasi dalam ruang pendidikan. Dalam memahami bentuk integrasi organisasi masyarakat sipil terkait dengan pendidikan kearifan lokal kemudian menjadi cukup penting untuk ditelaah dan dikaji lebih lanjut sehingga lebih memahami substansi dan peran serta implementasi keberadaan kelompok masyarakat atau organisasi masyarakat melalui dunia pendidikan.

\section{HASIL DAN PEMBAHASAN}

Setiap komunitas memiliki cara untuk menyelesaikan permasalahan dan memenuhi kebutuhan nilai dasarnya. Masyarakat sipil sebagai komunitas menjadi bagian yang turut mengimplementasikan pandangan serta aktivitas yang mendukung ketercapaian pembangunan demokrasi masyarakat. Definisinya tentunya cukup beragam, tidak hanya dalam kancah politik, ekonomi, namun sekali lagi adalah dunia pendidikan yang tidak pernah dapat lepas sepanjang hayat. Proses perubahan dinamis pendidikan tentunya dipertimbangkan dengan berbagai aspek yang berada di dalamnya.

Organisasi masyarakat sipil (Suharko, 2005) memiliki kepedulian yang berhubu ngan dengan tujuan-tujuan publik daripada tujuan-tujuan privat. Kepedulian itu menjadi satu wujud nyata yang benar-benar diperlukan masyarakat untuk memberikan satu nuansa atau bahkan pencerahan terhadap berbagai bidang permasalahan kehidupan yang ada. Ketika kemudian diimplementasikan dengan pendidikan kearifan lokal dapat lahir sebagai sebuah kreativitas suatu komunitas dalam memecahkan masalah atau memenuhi kebutuhannya dengan mengadopsikan sistem nilai yang dipahami dalam konteks dunia pendidikan. Berorientasi isu sebagai nilai dasar sebuah organisasi masyarakat sipil tentunya dapat menterjemahkan situasi yang terjadi. Geraka-gerakan untuk perlindungan, reformasi lahan, perlindungan konsumen dan hak-hak perempuan menjadi cukup penting diperhatikan untuk kesejahteraan masyarakat. Komunitas organisai masyarakat sipil tertentu seperti misalnya Walhi (Wahana Lingkungan Hidup) dan Kehati merupakan berbagai bentuk contoh OMS yang bergerak terintegrasi dengan dunia pendidikan berbasis kearifan lokal. Kekayaan cara pandang, nilai-nilai, konsep, teori, metode, teknik terintegrasikan melalui upaya kerjasama institusi pendidikan de ngan komunitas-komunitas masyarakat.

Sebagai contoh Walhi yang merupakan suatu bentuk OMS yang memposisikan diri sebagai wahana yang mensinergikan gerakan advokasi lingkungan hidup. Dengan mengemban nilai sebagai pejuang penegakan kedaulatan rakyat dan demokrasi untuk pemenuhan keadilan, pemerataan sosial, pengawasan rakyat serta kebijakan pengelolaan lingkungan dan sumber kehidupan dan pemetrintahan yang adil dan demokratis (Kehati, 2004). Dalam koefisien aktivitas dan prinsip OMS seperti di atas tentunya akan tersinergi dengan sistem atau kurikulum pendidikan yang sedang dibutuhkan di negara ini. sistem atau kurikulum pendidikan yang mengutamakan kearifan lokal menjadi tersinergi dengan keberadaan komunitas atau OMS yang 
demikian.

Pendidikan berbasis kearifan lokal yang merujuk pada sebuah nilai universal tentang keadilan sosial, kesejahteraan masyarakat dan kelestarian sumberdyaa penghidupan masyarakat yang dapat melandasi pola hubungan antar warga maupun dengan komunitas. Tidak dapat disebut kearifan apabila yang terjadi adalah adanya ketidakadilan, kemiskinan, kelaparan, kerusakan ekosistem dan penindasan. Dengan demikian menjadi sangat penting untuk dapat meninjau keberadaan sistem lokal serta dinamika perubahan untuk dapat dikatakn sebagai bentuk kearifan (Bima Widjajaputra, $t \mathrm{t}$ ). Perlu disampaikan bahwa kurikulum atau sistem pendidikan berbasis kearifan lokal itu sendiri menjadi nuansa baru dalam dunia pendidikan pasca terjadi gempa dan berbagai bencana alam di negara ini. Dobrakan baru mengenai sistem dan proses pendidikan sa ngat menjadi penting sebab pasca terjadi nya berbagai macam bencana alam kondisi rekonsiliasi baik secara mental maupun fisik masyarakat sangat diperhatikan. Masyarakat diberdayakan, dibangun dengan kesadaran yang nyata bahwa masyarakat dapat kembali bangkit untuk kehidupannya.

Kadangkala cukup sulit untuk mengidentifikasi bentuk kearifan lokal yang dapat diintegrasikan dalam sebuah kelompok atau organisasi masyarakat. Ketika berbicara mengenai hal ini tentunya kita berbicara mengenai peran serta bentuk nyata tentang pengintegrasian yang dimaksud dalam hal ini. Kelompok, komunitas dan kemudian Organisasi Masyarakat yang ada memiliki peran dalam membentuk sebuah interaksi antara pihak instansi pendidikan atau lembaga pendidikan untuk membangun komunikasi dengan kelompok, komunitas di masyarakat. Sekali lagi perlu dicatat ini adalah bentuk sistem pendidikan berbasis kearifan lokal yang menekankan pada tersinerginya kekuatan lokal, kelompok lokal dalam dunia pendidikan. Interaksi yang diciptakan kemudian diharapkan mampu memebentuk lokalitas sistem yang saling berhadapan sehingga kemudian muncul ide-ide baru, teori maupun metode antar lembaga pendidikan dan komunitas dengan bentuk kearifan. Apalagi kondisi alam maupun lingkungan sosial yang mengalami perubahan dari waktu ke waktu kemudian dapat mendorong munculnya kearfian baru dalam sebuah kehidupan masyarakat.

\section{Sekolah sebagai Ruang Partisipasi Sosial}

Dalam konteks yang dapat diungkapkan mengenai pentingnya integrasi organisasi masyarakat dalam proses implementasi sistem maupun kurikulum berbasis kearifan lokal adalah yang terjadi di wilayah Pajangan, Bantul, Yogyakarta. Setelah ditemukannya hasil penelitian sebelumnya bahwa keberadaan pabrik garmen di lingkungan masyarakat menyebabkan ibu-ibu rumah tangga terkonsentrasi pada aktivitas pekerjaan di pabrik sehingga untuk perhatian serta wujud pendidikan anak di lingkungan rumah terabaikan. Hal ini kemudian mendasari pemikiran lembaga pendidikan formal terkait salah satunya SD Sendangsari bersama dengan Sanggar Anak Bumi Tani untuk memecahkan permasalahan itu dengan mengadakan sebuah pelatihan multipihak (SD Sendangsari dan Sanggar Anak Bumi, 2011) bagi masyarakat terutama ibu-ibu untuk mengolah bahan pangan lokal dengan harapan mampu untuk saling bekerjasama dengan anak yang telah memperoleh pendidikan tersebut di sekolah (SD Sendangsari). Tentunya ketika SD Sendangsari akan terjun ke masyarakat dalam hal ini memerlukan partisipasi dan penginte grasian dengan organisasi masyarakat dan dukungan pemerhati lingkungan. Sekali lagi inilah wujud pembentukan atau penginte grasian potensi pendidikan dengan bentukbentuk kearifan lokal. Cara-cara seperti inilah yang dibutuhkan sekarang oleh masyarakat. Mungkin terlihat sederhana, berskala kecil dan sebagainya. Namun disadari atau tidak justru cara inilah yang saat ini menjadi benar-benar diperlukan untuk kelangsungan kehidupan masyarakat selanjutnya.

Keberadaan SD Sendangsari di tengahtengah masyarakat Sendangsari dapat dikate gorikan sebagai pola sekolah masyarakat yang mana adanya keterlibatan anggota masyarakat baik individu maupun kelompok so- 
sial. Sekolah dan masyarakat bersama-sama menjadi agen pendidikan dan partisipasi so sial sesuai dengan fungsinya. Sumber-sumber dari masyarakat menjadi bahan pembelajaran yang diselaraskan dengan kondisi masyarakat. Lingkungan belajar di luar sekolah menjadi faktor yang mempengaruhi pelaksanaan pendidikan. Bagaimanapun antara masyarakat dan sekolah terjadi hubungan yang saling mempengaruhi. Perubahan sistem sosial dapat mempengaruhi perubahan pendidikan dan sebaliknya. Ketika SD Sendangsari menginisiasi inovasi model pembelajaran, mempengaruhi perubahan dalam sistem sosial di sekitarnya. Pengaruh yang dapat dilihat terutama dalam hal partisipasi. Adapun pihak-pihak yang terlibat dalam pelaksanaan inovasi model pembelajaran di SD Sendangsari adalah orang tua, masyarakat, organisasi sosial setempat, dan swasta.

Proses kedekatan antara sekolah dan masyarakat menjadi salah satu faktor relasi eksternal yang diterapkan di SD Sendangsari. Peran pendidik dan proses pembelajaran tidak hanya ketika bertemu guru di sekolah atau belajar di kelas, melainkan partisipasi masyarakat dalam mendukung kegiatan belajar mengajar. Salah satunya yang dilakukan para siswa SD Sendangsari dengan belajar bersama di luar sekolah dengan menggunakan fasilitas yang disediakan warga masyarakat yakni sarana belajar berupa buku-buku dan kelompok belajar. Pihakpihak di luar sekolah memiliki peran dalam pelaksanaan pendidikan di SD Sendangsari. Dengan memadukan konsep implementasi nilai-nilai kearifan lokal sebagai substansi pembelajaran, hal ini mampu dijadikan sebagai ruang partisipasi bagi komunitas masyarakat sipil setempat atau melalui pendekatan berbagai unsur sumberdaya lokal yakni:

\section{Paguyuban Kearifan Lokal Orang Tua Murid}

Paguyuban Kearifan Lokal merupakan kelompok yang dimiliki SD Sendangsari bekerjasama dengan orang tua/ wali. Paguyuban ini berdiri dengan latar belakang keinginan untuk dapat berpartisipasi dalam kegiatan sekolah. Berawal dari kegiatan yang dilakukan anak-anak mereka dalam mengolah bahan makanan lokal, kemudian karena minat orang tua cukup besar maka sekolah mewadahi untuk membentuk kelompok ini.

Fokus kegiatan pada pengolahan bahan makanan lokal seperti emping dan tepung gadung yang dapat dimanfaatkan sebagai bahan pokok membuat kue tradisional. Berawal dari umbi-umbian yang sangat melimpah di Desa Sendangsari dan kurang dimanfaatkan oleh masyarakat, kemudian dikembangkan berbagai bahan makanan lokal yang lain. Selain itu karena mayoritas orang tua/wali murid juga bekerja sebagai penderes kelapa, mereka mengembangkan olahan produk gula kelapa mereka. Berawal dari coba-coba akhirnya produk tersebut laku dijual dan menambah pendapatan.

Tugas guru dan karyawan SD Sendangsari sebagai pelatih pengolahan makanan selanjutnya fasilitator Sanggar Anak Bumi Tani menjadi pengembang jaringan dan menjadi konsultan untuk berbagai produk olahan dari segi manfaat, nutrisi dan pengemasan. Keterbatasan para orang tua adalah dalam penjualan produk. Maka hasil-hasil produk olahan Paguyuban Kearifan Lokal ini dijual atau dipamerkan melalui sekolah dalam berbagai kegiatan dan dibantu Sanggar Anak Bumi Tani dalam berbagai kegiatan mitra jaringannya. Di luar dugaan, ternyata banyak yang menggemari dan belajar. Hingga akhir nya pendapatan para orang tua pun bertambah dan mereka mulai menerima pesanan berbagai makanan olahan yang bersumber dari makanan lokal.

Selain kegiatan pengolahan makanan lokal setiap kali pertemuannya, sekolah bersama Sanggar Anak Bumi Tani memfasilitasi Paguyuban Kearifan Lokal SD Sendangsari untuk belajar ke luar atau studi banding ke Purworejo tentang penolahan makanan lokal. Kegiatan tersebut diikuti oleh orang tua/ wali, siswa dan guru serta didampingi oleh Sanggar Anak Bumi Tani. Antusiasme para. Orang tua dan siswa mengikuti kegiatan tersebut selanjutnya mereka mengembangkan berbagai macam inovasi produk olahan di rumah dan di sekolah. 
Relasi yang kemudian diciptakan antara Paguyuban Kearifan Lokal dan proses pembelajaran di sekolah adalah terjadi sebuah proses pendekatan terhadap model pembelajaran di sekolah. Orang tua dan masyarakat memiliki peran dan adil yang cukup besar dalam penyelenggaraan inovasi model pembelajaran berbasis sumberdaya lokal di SD Sendangsari. Keterlibatan orang tua dan dalam hal ini juga masyarakat dirasakan betul oleh pihak SD Sendangsari baik guru, Kepala Sekolah, siswa maupun karyawan. Meskipun pada awalnya orang tua kurang begitu memperhatikan terhadap model pembelajaran berbasis sumberdaya lokal, setelah orang tua mengetahui dan memahami bahwa proses pembelajaran tidak hanya melalui materi-materi pengetahuan seperti biasanya namun dengan media berbagai sumberdaya lokal yang ada di sekitarnya, mereka pun memberikan dukungan dan partisipasi untuk turut mendidik anak di rumah.

Dibalik ada kepentingan ekonomi bagi orang tua atau masyarakat, namun hal itu secara tidak langsung tentunya juga akan mempengaruhi kondisi peserta didik. Ketika kebutuhan ekonomi peserta didik terpenuhi maka kondisi di sekolah akan lebih bersemangat. Sehingga konsep model pembelajaran berbasis sumberdaya lokal ini mampu memberikan dukungan dan pemberdayaan terhadap masyarakat. Materi-materi yang diberikan di sekolah seperti misalnya pengolahan umbi gadung, pembuatan batik dan seterusnya kemudian dibelajarkan di rumah pula. Orang tua melalui Paguyuban Kearifan Lokal telah mendapatkan materi dan arahan dari sekolah. Kemudian secara bersama-sama berdiskusi di rumah dan menciptakan produkproduk lokal lainnya. Setelah proses tersebut kemudian di sekolah dilakukan proses evaluatif. Seperti itu seterusnya hingga kemudian siswa dan orang tua mampu untuk mengembangkan kemampuan pengolahan potensi kearifan lokal berupa makanan dan produkproduk lainnya seperti batik. Ketika sekolah melaksanakan ujian kegiatan ekstrakurikuler terpadu atau sekolah mengadakan pameran, orang tua pun dilibatkan dalam kegiatan sekolah. Jadi tidak hanya siswa dan guru saja, namun justru langsung dalam hal ini terjadi sebuah proses pembelajaran kepada masyarakat dan masyarakat merasakan sendiri keterlibatan mereka dalam penyelenggaraan pendidikan di sekolah.

Melalui hal tersebut secara terusmenerus dapat dirasakan dampak yang tidak hanya dialami oleh orang tua namun masyarakat lainnya. Orang tua siswa yang sebelumnya belajar mengolah variasi makanan lokal dan batik hanya untuk kepentingan anak, kemudian menularkan kepada tetangga lain sehingga masyarakat mulai meniru. Masyarakat kemudian belajar mengolah makanan lokal yang selama ini mereka biarkan begitu saja. Masyarakat mengembangkan produksi batik karena permintaan batik semakin ba nyak. Sehingga masyarakat pun tertular untuk mengembangkan inovasi yang lain. Secara tidak langsung orang tua memberikan peran positif kepada sekolah dan sebaliknya.

\section{Partisipasi Organisasi "Karang Taruna”}

Keterlibatan masyarakat dalam proses pendidikan di SD Sendangsari lainnya terwujud pada terjalinnya mitra dengan Organisasi Sosial masyarakat setempat dalam hal ini Karang Taruna Desa Sendangsari. Kegiatan kemitraan yang dilakukan adalah terkait dengan aktivitas pendidikan seperti tulismenulis atau pembuatan koran anak dan media sekolah.

Kegiatan ini merupakan kegiatan yang dilaksanakan dengan pelatihan tulis-menulis, wawancara, fotografi kemudian penerbitan koran anak dan media. SD Sendangsari merasa perlu untuk menjalin kerjasama dengan masyarakat luas dalam hal ini salah satunya Karang Taruna setempat agar para siswa termotivasi dan pengurus Karang Taruna dalam hal ini pemuda dapat berbagi pengalaman. Selain itu Karang Taruna sebagai organisasi yang bergerak dalam bidang sosial juga memiliki visi untuk melestarikan nilai-nilai kearifan lokal di Sendangsari. Sehingga melalui partisipasi mereka dalam bidang pendidikan itulah, mereka turut menyampaikan kepada siswa SD Sendangsari tentang potensi lokal, masyarakat, organisasi dan sebagainya. 
Peran Karang Taruna sebagai organisasi sosial pemuda setempat menjadi cukup menarik ketika dipadukan dengan penyelenggaraan pendidikan di sekolah. Proyeksi atas kesempatan untuk saling mendukung dalam kegiatan akademik maupun non akademik dapat disatukan melalui berbagai aktivitas sekolah dan karang taruna itu sendiri. Konsep partisipasi sosial menjadi begitu terlihat tatkala munculnya keterlibatan pemuda dalam hal ini melalui Karang Taruna yang mampu menularkan berbagai konsep dan pengetahuan sosial masyarakat ke dalam sekolah. Sehingga dari sinilah muncul sebuah keterkaitan erat antara sekolah dan organisasi sosial setempat dalam hal ini organisasi kepemudaan.

\section{"Sanggar Anak Bumi Tani" sebagai Pengembang Jejaring}

Sanggar Anak Bumi Tani merupakan sebuah lembaga swadaya masyarakat yang beralamat di Rajek Lor Dn 12, Tirtoadi, Mlati Sleman. Sanggar yang bergerak dalam kegiatan lingkungan dan pendidikan ini memulai perkenalan dengan SD Sendangsari ketika pasca gempa. Kegiatan Sanggar Anak Bumi Tani tentang lingkungan, pertanian serta pendidikan selaras dengan yang dilaksanakan oleh SD Sendangsari. Disebutkan oleh Kepala Sekolah SD Sendangsari waktuitu, bahwa kerjasamayang dilaksanakan SD Sendangsari dan Sanggar Anak Bumi Tani berawal dari keinginan SD Sendangsari untuk melaksanakan aktivitas pembelajaran yang bervariatif dan Sanggar Anak Bumi Tani yang memiliki jaringan serta konsep pendidikan bervariatif untuk sekolah.

Kerjasama SD Sendangsari dengan Sanggar Anak Bumi Tani berlanjut melalui kegiatan-kegiatan di SD Sendangsari. Manfaat yang dirasakan sekolah dan anak-anak cukup banyak. Tatkala sekolah memerlukan mitra dan jaringan yang luas untuk mengembangkan dan mensosialisasikan inovasi model pembelajaran di sekolah, Sanggar Anak Bumi Tani memfasilitasi dengan jaringan dan relasi mereka untuk bekerjasama dengan SD Sendangsari.
Selanjutnya menjadi relasi sosial yang cukup penting atas keberlangsungan pengembangan pendiidkan di SD Sendangsari adalah keterlibatan LSM dalam hal ini Sanggar Anak Bumi Tani sebagai mitra kegiatan. Keterbatasan SD Sendangsari dalam jaringan dan pengembangan inovasi pembelajaran terpecahkan saat menjalin relasi dengan para penggiat pendidikan di LSM tersebut. Yang tidak dimiliki oleh sekolah adalah jaringan/ networking atas kegiatan pendidikan, maka itulah yang dijawab dan disambung oleh LSM. SD Sendangsari dengan konsep kearifan lokal dan hak-hak anak dengan konsep pemberdayaan masyarakat adalah konsep yang tidak jauh berbeda dengan yang dilakukan oleh LSM. Maka LSM Sanggar Anak Bumi Tani mengembangkan jaringan SD Sendangsari untuk terlibat aktif dalam kegiatan-kegiatan kearifan lokal. Misalnya disebutkan terlibat dalam pertemuan Internasional Kearifan Lokal bersama Wahana Lingkungan Hidup, menjadi peserta Workshop Regional Asia Pasific "Regional Peasents Feeding the Word" di Ngandong Gantiwarno Klaten, Peserta kegiatan Hari Pangan se Dunia ke-29, Peserta Temu Kearifan lokal se-jawa dan Bali, dan lain sebagainya. Hal ini tentunya membawa dampak positif bagi civitas akademika sekolah. Pengalaman, proses belajar dan berbagai keterampilan diasah sehingga anak-anak tidak sebatas belajar di lingkungan kelas dan sekolah namun memiliki pengalaman yang membuat mereka lenjadi lebih terampil, berani dan kreatif.

\section{Social Empowerement dan Relasi Sosial Komunitas Masyarakat Sipil}

Pada konteks ini, pemberdayaan (empowerement) menjadi satu hal yang di garisbawahi. Kapasitas relasi sosial sekolah bersama masyarakat dan organisasi sosial sebagai penopang penyelenggaraan pendidikan tentunya muncul tidak hanya sekedar atas kepentingan sekolah dan penyelenggaraan pendidikan. Meninjau jauh ke depan ketika dikisahkan oleh seorang guru di sekolah tersebut ia menemukan peserta didik yang kurang mendapatkan perhatian orang tua dikarenakan sibuk bekerja dari 
pagi hingga malam menjadi buruh atau pekerja kasar lainnya, ini membuktikan bahwa kondisi ekonomi sebagian besar orang tua/ wali berada pada garis kemiskinan. Miskin dalam arti untuk memnuhi kebutuhan pokok belum dapat terjangkau dengan baik. Ketika sekolah mengupayakan sebuah ke giatan atau program pendidikan yang dapat disambut oleh orang tua/ wali hal itu tidak lepas karena kondisi perekonomian yang membuat mereka tertarik untuk bergabung dalam kegiatan sekolah. Berikutnya, terkait kegiatan pemberdayaan tersebut. Pemberdayaan merupakan sebuah konsep pemba ngunan yang melibatkan beberapa konsep penting. Pemberdayaan mengandung konsep : penekanan pada ekspansi aset dan kemampuan kelompok miskin, perluasan aset dan kemampuan digerakkan dan difasilitasi dengan cara-cara mengedepankan partisipasi, negosiasi, ekuntabilitas dan risk-sharing, dan fokus pemberdayaan adalah kelompok miskin yang memiliki keterbatasan akses pada sumberdaya (resources) ekonomi dan politik yang hidup pada kondisi kehilangan akses kebutuhan dasar.

Cara-cara yang dilakukan dalam hal ini institusi sekolah bekerja sama dengan LSM merupakan cara-cara praktis partisipasi yang sebelumnya jarang dilakukan di sekolah lain di Bantul. Ada sebuah pendapat yang mengemukakan pula bahwa dari ber bagai pengalaman, intervensi yang dilakukan oleh kelompok miskin yang dilakukan pihak luar (pemerintah, swasta, lembaga swadaya masyarakat dan lembaga donor) acapkali memperlihatkan wajah yang kreatif namun desdruktif (Sunyoto Usman, 2010:2). Namun kenyataan di SD Sendangsari lain. Proses partisipasi masyarakat dalam pendidikan membawa dampak konstruktif bagi anak maupun orang tua itu sendiri terkait program pembelajaran maupun terbebasnya dari ketidakmampuan memenuhi kebutuhan ekonomi. Risk-sharing mampu untuk diatasi sedemikian rupa karena sekolah dan lembaga mitra kegiatan mengutamakan proses diskusi dan problem solving secara bersamasama sesuai kebutuhan. Akhirnya tidak ada sebuah proses pemaksaan namun kesadaran yang membuat relasi sosial tersebut berjalan dengan apa adanya. Keberadaan sekolah dan LSM justru memberikan dampak positif terhadap adanya keterbatasan akses pada sumberdaya (resources) ekonomi dan politik bagi masyarakat.

Masyarakat yang terbatas pada pengetahuan minim menjadi lebih mengerti dan memahami tentang pemanfaatan sumberdaya alam di sekitar, sehingga ketergantungan kepada pemilik lahan pertanian yang menjadikan mereka sebagai buruh dengan upah kerja minim pun dapat disiasati. Wacana dan pengetahuan pemanfaatan hasil alam masyarakat menjadi lebih kreatif, selain itu secara tidak langsung mereka bersamasama mendukung anak mereka untuk belajar. Masyarakat juga bukan sebagai bagian dari sekolah yang bersifat pasif dalam pengambilan keputusan dan kebijakan sekolah. Pada proses ini masyarakat kemudian berani mengemukakan ide-ide yang kemudian dibahas dalam konsep pembelajaran di sekolah. Hal ini tentunya sebagai bagian yang tidak dapat dipisahkan dari adanya peningkatan kemampuan partisipasi masyarakat.

\section{Sekolah dan Masyarakat sebagai Ruang Transformasi Budaya}

Masing-masing sekolah memiliki kebudayaan. Sekolah merupakan institusi sosial yang dapat mempengaruhi proses sosialisasi dan dapat mewariskan kebudayaan kepada para komponen di dalam dan sekitarnya. Layaknya keluarga, sekolah merupakan sistem sosial yang memiliki organisasi dan pola relasi sosial diantara para anggotanya. Itulah yang disebut kebudayaan sekolah (Abu Ahmadi, 2004:187). "A complex set of beliefs values and traditions, way of thinking and behaving". Kebudayaan sekolah merupakan rangkaian dari sistem kepercayaan nilai dan tradisi, jalan untuk berpikir dan bertingkah laku. Hal ini membedakan dari ins titusi lainnya. Kebudayaan sekolah memiliki unsur penting :

- Letak lingkungan dan prasarana fisik sekolah

- Kurikulum sekolah dengan gagasangagasan maupun fakta-fakta yang men- 
jadi keseluruhan program pendidikan

- Pribadi-pribadi yang merupakan warga sekolah terdiri atas siswa, guru, tenaga administrasi dan karyawan

- Nilai, norma, sistem peraturan dan iklim kehidupan sekolah

Sebagai bagian dari lingkungan sosial dan kehidupan di sekitar sekolah, insitusi seperti sekolah tentunya memiliki kesempatan untuk dapat berinteraksi dengan lingkungan tersebut. Jejaring muncul tatkala ada komunikasi dari sekolah bersama lingkungan di luar sekolah dalam hal ini adalah berbagai macam komunitas sosial. Arena belajar dan transformasi budaya akan terus tercipta tatkala terjadi berbagai macam aktivitas sosial di dalam lingkungan tersebut. Sekolah dan komunitas sosial yang ada di masyarakat te rus bersinergi dalam melaksanakan berbagai aktivitas baik pendidikan maupun aktivitas sosial. Keterpaduan keduanya merupakan salah satu media sosialisasi yang cukup penting bagi masyarakat.

\section{SIMPULAN}

Suatu proses keberadaan masyarakt sipil di masyarakat terutama dunia pendidikan merupakan proses panjang yang perlu dipahami sebagai investasi. Pendidikan tidak kemudian berimbas secara langsung seperti kancah perpolitikan namun melalui pendidikan tertanam berbagai macam proses serta prinsip-prinsip nyata yang diimplementasikan oleh masyarakat. Pendidikan menaungi kepentingan masyarakat akan terjadinya proses pemahaman terhadap situasi dan kondisi masyarakat, bangsa dan negara. Ini kekuatan demokratis rakyat yang sebenar nya. Kekuatan demokratis tidak hanya sekedar untuk berpolitik, berpartisipasi dalam kancah pemilihan dan sebagainya tapi urgensinya adalah satu prinsip dimana masyarakat benar-benar mengalami proses pemhaman yang nyata tentang keberadaan kepentingankepentingan publik yang kemudian mampu menemukan berbagai bentuk tawaran serta sistem yang ada di negara ini.
Organisasi masyarakat sipil yang memiliki landasan nilai informasi dan pendidikan dengan mencurahkan dirinya pada sisi produksi dari penyebaran pengetahuan umum, ide-ide, berita dan informasi publik. Inilah satu landasan atau nilai yang mampu mendasari prinsip perlunya organisasi masyarakt sipil untuk dapat menaungi kepentingan publik dalam berbagai kepentingan pengetahuan, ide dan pola umum masyarakat yang berkembang. Masyarakat memerlukan bentukan-bentukan baru mengenai pola-pola atau sistem kehidupan yang sekali lagi tujuannya sedehana yakni kesejahteraan masyarakat tersebut.

Pengintegrasian organisasi masyarakat sipil dalam kancah pendidikan berbasis kearifan lokal memang terlihat sebagai satu bentuk pijakan kecil yang ada dalam kehidupan bermasyarakat. Namun ini bisa dikatakan sebagai 'cadangan pengaruh' yang akan melahirkan bentukan-bentukan baru berwujud investasi publik terhadap adanya satu kesempatan masyarakat atau komunitas untuk mengembangkan dunia pendidikan. Demokrasi tidak hanya dalam kancah politik 'melulu' tentang adanya kekuasaan, partai politik dan sebagainya. Tapi sekali lagi demokrasi melahirkan kepentingan hajat hidup orang banyak yang berada pada masyarakat itu sebenarnya. Organisasi masyarakt sipil dapat menjadi jembatan yang nyata melalui aktivitas pendidikan, pemberdayaan masyarakat secara sederhana yang justru melahirkan sebuah simpul-simpul pemahaman serta implementasi nyata nilainilai dasar dan transformasi budaya dengan ada nya organisasi masyarakat sipil. Memba ngun masyarakat, mewujudkan kepentingan masyarakat, mengindikasikan kesejahteraan masyarakat dengan cara-cara berbasis kearifan lokal masyarakat melalui sekolah dan komunitas masyarakat sipil.

\section{UCAPAN TERIMA KASIH}

Terima kasih kepada Masyarakat Sen dangsari, SD Sendangsari, Organisasi 
Pemuda Karang Taruna Desa Sendangsari, Sanggar Anak Bumi Tani dan berbagai pihak yang membantu proses penelitian ini. Semoga hasil penelitian ini bermanfaat untuk perkembangan proses pendidikan selanjutnya baik di sekolah ataupun di masyarakat.

\section{DAFTAR PUSTAKA}

Ahmadi,Abu. 2004. Sosiologi Pendidikan. Jakarta: PT Rineka Cipta.

Diamond, Larry. 2003. Developing Democracy: Toward Consolidation. Yogyakarta: IRE Press.

Gunawan, Ari. 2000. Sosiologi Pendidikan : Suatu Analisis Sosiologi tentang Pelbagai Problem Pendidikan. Jakarta: PT Rineka Cipta.

Kehati. 2004. Umbi-Umbian yang Berjasa yang Terlupa. Yogyakarta: Simpul Pangan Yogya dan Yayasan Kehati.
Depdiknas. 2006. Undang-Undang Republik Indonesia Nomor 14 Tahun 2005 tentang Guru dan Dosen. Bandung: Citra Umbara. . Undang-Undang Republik Indonesia Nomor 20 Tahun 2003 tentang Sisdiknas, Bandung: Citra Umbara.

SD Sendangsari dan Sanggar Anak Bumi Tani. 2011. Tor Pelatihan Multipihak. Yogyakarta.

Suharko. 2005. Masyarakat Sipil, Modal Sosial, dan Tata Pemerintahan yangDemokratis. Jurnal Sosial dan Politik. Fisipol UGM, Vol. 8, No. 3, Maret. ISSN 1410-4946

Sumitro dkk. 2006. Pengantar Ilmu Pendidikan. Yogyakarta : UNY Press.

Usman, Sunyoto. 2010. Handout Mata Kuliah : Pemberdayaan (Empowerement), UGM : Jurusan Sosiologi.

Widjajaputra, Bima. tt. Berbasis Kearifan Lokal. Catatan Khusus tentang Kearifan Lokal. Yogakarta: Sanggar Anak Bumi Tani. 